\title{
Gradually building and promoting the initiative and creativity of Vietnamese workers in the period of international economic integration
}

\author{
Huynh Tuan Linh, Nguyen Van Duong \\ Ho Chi Minh City University of Food Industry
}

\begin{abstract}
In the context of deepening international integration, the requirement for the quality of Vietnamese human resources is to prepare the workforce to be able to meet and benefit from international commitments. Although, Vietnam is in the golden population period with an abundant and stable labor supply, but the integration trend has also put Vietnam in front of many new opportunities and challenges. The integration trend will lead to a very high competitiveness in the human resource market, while the readiness level of Vietnamese workers is still slow. Competition between Vietnam and other countries in the world in providing high-quality labor is increasing, requiring the quality of workers to be significantly improved in the direction of approaching regional and world standards. Faced with that fact, the issue of improving the quality of labor resources with high productivity, intelligence and creativity in order to promptly meet the growth requirements of the economy is of great interest to the State and Vietnamese enterprises. This is an important element of the foundation for sustainable development and increasing national competitive advantage, a breakthrough in the strategy of transforming the country's socio-economic development model.
\end{abstract}

Keywords: Proactivity, creativity, employees, human resources, integration, international economy.

\section{MAKE A PROBLEM}

$\mathrm{P}$ roactivity and creativity are inherent attributes of human in social life. It is the enthusiasm, enthusiasm and determination of employees in meaningful activities to promote the development and progress of society. The initiative and creativity of employees is expressed as: spirit of enthusiasm, enthusiasm, determination, initiative and creativity of people in the working process. With the initiative and creativity of employees, it will have a great impact on work efficiency, and is an important measure to evaluate the quality of human resources. The current human resource situation is difficult to allow to make the best use of the opportunities that are coming to the country. Therefore, if the problem of improving the quality of human resources cannot be solved in the near future, Vietnam will face the risk of a crisis in the quality of human resources, the consequence of which is a decrease in competitiveness; difficult to escape from the "middle income trap"; lost the opportunity to participate in the international labor market.
In the period of deep international integration, labor movement between countries takes place frequently. Vietnamese workers must gradually improve to adapt and compete with international workers, and the issue of promoting the initiative and creativity of Vietnamese workers becomes more and more urgent (Mai Quoc Dung, 2021). Therefore, doing research to properly assess the activeness and creativity of employee today and then propose some recommendations to improve the initiative and creativity of employees, contributing to improving the quality of human resources, meeting the requirements of the national renewal process.

\section{THE INITIATIVE AND CREATIVITY OF VIETNAMESE WORKERS TODAY}

\subsection{Some advantages}

The spirit of mastering labor, self-employment and trying to organize jobs in a reasonable way: With creative nature, flexibility and quick adaptation when moving from a centralized, bureaucratic, inclusive economy transitioning to a socialist-oriented market economy, Vietnamese workers quickly gained new perceptions, including awareness of employment. Workers have actively organized jobs in many different forms. They themselves are free to conduct contracts with state, collective and private units according to the law. They opened many professions and organized production facilities, which attracted the social labor force. This is an activity of great socio-economic significance. On the one hand, they actively participate in the economic development of the country, on the other hand, they actively contribute to solving pressing social problems that are labor and employment for workers.

Employees actively find many new business forms, rapidly increasing wealth for the society: From the reality of production and business, employees have actively applied many new forms of production and business, organized dynamic and appropriate economic activities in the form of private individuals, individuals and households in a number of fields in order to promote and expand production and trade in goods. This trend develops more and more widely in industry, agriculture, forestry and handicrafts... 
The prosperity of the economy under the market mechanism is an affirmation of the positivity of employees, while promoting more dynamism in production and business activities, promoting profitable businesses. At the same time, the market economy will screen, select and foster a contingent of workers, entrepreneurs and managers, contributing to socialist-oriented economic growth.

Improving the level of production and business, the level of management, the application of scientific and technological achievements to production and business to accelerate the economic development process: The fierceness of competition in the market mechanism strict requirements for businesses and workers, including in the state-owned sector, collectives, individuals, and households, etc. Because they have improved their qualifications, production skills, and management skills. Only then can we stand firm and develop in the market mechanism. Workers who want to survive and develop must pay attention to scientific and technological achievements and apply them to the production process. The country's education and training system equips workers with basic knowledge of science and technology, which has gradually overcome the initial difficulties and challenges (Pham Thi Hong Nhung, 2020, p. 43-46).

\subsection{Some limitations}

In addition to the achieved results, in recent years of renovation, the activeness of Vietnamese workers also has certain limitations, which are:

The ability to apply scientific and technological achievements and use modern machinery and equipment in production is still limited: In order to build a highly developed economy based on a modern production, the problem of The most important part of the process of industrialization and modernization of the country is the application of scientific and technological achievements to all economic branches, bringing modern machinery and equipment suitable to our country's conditions. The problem depends on how workers apply them to production?

The current reality shows that the quality of human resources in Vietnam is still low, slow to be improved, not meeting the requirements of the country's development; Education and training, science - technology is not really the leading national policy. The structure of occupations by labor is not reasonable, there is a shortage of many highly qualified experts and a lack of a team of good managers, businessmen and skilled workers. Trained laborers are few and of limited quality.

A part of employees expect and rely on the guidance of the leader, on the collective opinion, looking for a model to apply, an example to learn, an opportunity to apply: They have not mastered the work, have not automatically proposed production plans, improved science and technology; propose solutions to boost production and improve labor productivity. Since then, leading to the situation of many production and business establishments stomping on the spot, even going bankrupt or dissolved.

Production and business activities of workers mainly rely on capital, unsustainable development, so labor productivity is low: In recent years, our country's economy has operated under a growth model mainly based on capital. The maintenance of economic growth model mainly based on capital, low efficiency of capital use, spread, and inconsistent coordination among regions and sectors leads to underdeveloped economic status and labor productivity. Therefore, income is low compared to other countries in the region and the world.

Working people's life is still difficult, many pressing social problems are slow to be overcome: In recent years, the poverty rate in our country has decreased significantly (4\%), but up to now, some areas in some areas is still quite high (Xuan Anh, 2020). In addition, some social evils such as gambling, drugs, prostitution... have not been stopped.

The reasons for the above limitations stem from the following reasons:

The first is: The influence of political, cultural, scientific and technological ideological education on the process of promoting social positivity of employees. Developing education is a factor that positively affects the promotion of social positivity of employees. In which, political ideology education is an important factor to help employees form new political thinking. However, the content, programs, methods and objects of education are still limited. Therefore, creating a distraction, perfunctory, obligatory mentality in learning political theory, disregarding learning, and wasting the country's time and budget. Therefore, the political consciousness of workers is still limited. A part of workers is indifferent to the country's political issues, loses faith in civil servants, and causes actions that affect themselves, their families and the country such as embezzlement, corruption...

Second: Developing cultural, scientific and technological education is becoming an urgent issue. However, science and technology education and training still have many limitations such as: The quality of education and training is still low, especially vocational training and higher education; the education and training system is not synchronous; The scale of vocational education is small and of low quality; The gap in education between urban and rural areas is still large; Education in mountainous, deep-lying and remote areas is still weak; Conditions for teaching and learning at all levels are still inadequate, especially in remote and isolated areas, and ethnic minority areas; The teaching staff is lacking and of low quality, especially in vocational training and higher education; Curriculum content and educational methods are slow to innovate; Students' practical ability is still weak; Education management still has many shortcomings, negative phenomena in education and training are still common; Mechanisms and policies have not yet created an effective 
connection between research and training, production and business; The application efficiency of scientific research works is low; The scientific and technological staff lacks both quantity and quality, and lacks leading experts and professionals in many fields; The policy of training, appreciating and rewarding science and technology staff has many shortcomings (ILO, 2020). It is these limitations that are the cause that negatively affect the promotion of human factors and improve the social positivity of employees.

Thirdly: The level of socio-economic development in our country is still low, workers lack the basic conditions for the promotion of creative capacity: In addition to the achievements, Vietnam's economy also has many advantages. manifestations of unsustainable development such as: The infrastructure system has developed slowly and is not synchronous, especially in highland, deep-lying and remote areas; The level of development between regions is still large and tends to expand; Indicators of economic growth and economic restructuring did not meet the set plan; Lack of capital, lack of science - technology still happens regularly; The disparity between rich and poor took place sharply; Unemployment rate is still high ( $\mathrm{VOH}, 2020)$. Besides, the reverse side of the market mechanism creates a part of employees who only focus on personal material benefits without paying attention to other issues such as morality, knowledge, will, and energy.

Fourth: Influence of the socio-economic management mechanism of the Party and the State on the process of promoting social positivity of workers: The movement of social positivity of Vietnamese workers does not separate the movement process by the socio-economic management mechanism. In the process of transitioning to a new socioeconomic management mechanism, the elimination of the negative effects of centralized management, bureaucracy and subsidies has achieved many important but not radical achievements. It can be said that the remnants of the centralized management mechanism, bureaucracy, subsidies; the incompleteness and lack of synchronization of the new economic management mechanism and especially the weakness of the management staff are the causes that negatively affect the promotion of the human factor, improve the social poles of workers.

\section{SOME RECOMMENDATIONS TO PROMOTE THE INITIATIVE AND CREATIVITY OF VIETNAMESE WORKERS}

3.1. To step up the education of political, cultural, scientific and technological ideas for employees

Political ideology education aims to raise the political consciousness of employees: Political ideology education is to equip the working people with basic knowledge about the lines and policies of the Party and State, to arouse to raise workers' interest in the nation's revolutionary cause, and to be more fully aware of the cause of national renewal initiated and led by the Party.

Promoting cultural, scientific and technological education for employees: To promote the social positivity of workers, it is necessary to arouse enthusiasm, determination, will and energy of employees. The basis and foundation to ensure the promotion of that positivity is the knowledge, scientific - technological and cultural level of the employees. This is the basis for forming human motivation, purpose, content, and program of activities.

\subsection{Focus on economic development, ensuring jobs and economic benefits for employees}

The urgent requirement at this time is to focus on strengthening the country's economic development, effectively solving unemployment for workers. To accomplish this task we need to: Continue to perfect the socialist-oriented market economic institution, to perfect the socialist-oriented market economic institution, it is necessary to master socialist orientation in the market economy in our country. To develop an economy with many forms of ownership and economic sectors, in which the state economy plays the leading role; In order to develop the economy, it is necessary to promote industrialization and modernization in association with the development of the knowledge economy. position of the country to shorten the process of industrialization and modernization; Focusing on building and creating breakthroughs in infrastructure, meeting the requirements of economic development, concentrating resources on construction, perfecting the essential transport system, especially in big cities, industrial parks, modernize a number of airports and seaports...; synchronously building job creation measures, mobilizing all resources to create a fast-growing economic environment, capable of creating many new jobs regularly and continuously, associated with employment solutions. Relocating and redistributing labor by regions, territories and economic sectors in line with the process of economic restructuring (Nguyen Tiep, 2005, p. 347-350).

In the current innovation period, focusing on socioeconomic development and ensuring benefits for employees is an urgent task in order to promote their social positivity. In order to well solve the problem of benefits for employees, it is necessary to: Build and maintain a mechanism for proper combination and harmonious settlement between material benefits and spiritual benefits for employees, because the Quality and spiritual benefits always require to be resolved in a harmonious way to really create motivation to stimulate positivity, initiative, creativity, enthusiasm and enthusiasm of employees; Building and maintaining a mechanism to properly combine and harmoniously deal with short-term and long-term interests requires a sustainable development strategy, that is, together with prioritizing the implementation of benefits. In the immediate future, in order to stimulate and exploit all potentials of employees, it is necessary to have an investment strategy soon to realize long-term benefits, create 
trust and, above all, create conditions to promote the positivity of employees. Workers in the construction of the country; In order to promote the social positivity of employees, it is necessary to build and maintain a mechanism for proper combination and harmonious settlement between the common interests and the private interests of the participants. Common interest is the benefit of many entities of the same type such as groups, collectives, communities, countries, etc... (Central Institute for Economic Management, 2012).

\subsection{Renovating the economic management mechanism,} perfecting social policies

Management plays an important role in promoting the human factor and it has the effect of enhancing the social positivity of employees. An appropriate management mechanism will establish the right socio-economic relationships through which people have conditions to fully express and demonstrate their capabilities in productive labor and social activities. . In order to improve the social positivity of employees, it is necessary to have a system with specific programs and measures:

Building a "people-centered" economic management mechanism: The new management mechanism must be associated with the liberation of all capacities of employees; The economic management mechanism must ensure the best combination between workers and means of production; Economic management mechanism must focus on human development and for people; Building a contingent of managers capable of organizing and implementing effective management activities in order to promote the social positivity of employees.

Building a system of correct social policies in order to promote the social positivity of employees: Social policies need to be consistent with economic policies, ensuring economic growth associated with progress and equity. society; The system of social policies must contribute to healthy social relations, building a just, democratic and civilized society; Solve social problems in the spirit of ensuring the harmony of interests between the parties involved.

\section{CONCLUSION}

After more than 75 years after the August Revolution, nearly 35 years since the implementation of the innovation policy set out by the Communist Party of Vietnam, Vietnam has risen from a poor country heavily affected by the war. Vietnam step by step achieved many great achievements, position in the international arena is increasingly solid. That success is due to the renewal determination of the Party and the aspiration of the people, in which the role of workers is particularly important. Besides the advantages, the activeness of employees also reveals certain limitations. Some parts of employees are still not fully and deeply aware of their meaning and role in labor activities, and their sense of discipline and responsibility for the common job is still not high. Attitudes of passivity, dependence, reluctance to approach the innovation of production technology, lack of creativity and passion for work still appear.

Therefore, in order to promote the advantages and overcome the limitations, it is necessary to have synchronous solutions from the State, enterprises and employees. Strengthen education and training, gradually improve skills and access to science and technology for employees; encourage and create conditions for enterprises to develop more and more, thereby creating many high-income jobs for employees; have comprehensive and substantive policies to support and promote the positivity of employees.

\section{REFERENCES}

[1] Central Institute for Economic Management (2012). The role of salary and income as driving force for sustainable economic growth, Thematic Economic Information.

[2] Dang Xuan Hoan (2015). Developing human resources to meet the requirements of industrialization, modernization and international integration, Communist Review, volume 4.

[3] Doan Thi Phuong Diep (2019). The relationship between employees and employers in the current period, Journal of Finance, volume 2.

[4] Hong Kieu (2021). Compete with human resources to not miss opportunities in the 4.0 era,

https://www.vietnamplus.vn/canh-tranh-bang-nguon-nhan-luc-dekhong-bo-lo-co-hoi- shuttle-dai-40/694186.vnp

[5] Mai Quoc Dung (2021). The Communist party of Vietnam leads the work of international integration from 1986 to 2021, Review of International Geographical Education Online, volume 11 (10).

[6] Nguyen Tiep (2005). Textbook of Human Resources, Labor and Social Publishing House, Hanoi.

[7] ILO (2020). The open economy changes the form, distribution, and quality of Vietnam's jobs, https://www.ilo.org/hanoi/Informationresources/Publicinformation /comments-and-analysis/WCMS_736066/lang--vi/index. htm

[8] Pham Thi Hong Nhung (2020). Some issues on sustainable economic development of Vietnam, Financial Review, volume 724.

[9] Pham Thi Thu Lan (2021). The labor market in a modern and complete market economy,

https://www.tapchicongsan.org.vn/web/guest/ Kinh-te//2018/821657/thi-truong-lao-dong- in-news-te-thi-truong-hiendai\%2C-day-du.aspx

[10] Xuan Anh (2020). The national average poverty rate is less than 4\%. https://nhandan.org.vn/tin-tuc-xa-hoi/ty-le-ho-ngheo-binhquan-can-nuoc-con-duoi-4-472886/.

[11] VOH (2020). In 2019, the national unemployment rate decreased. https://voh.com.vn/ Kinh-te/nam-2019-ty-le-that-nghiep-chungcan-nuoc-giam-349358.html. 